\title{
Eunice rubra Grube (Annelida, Polychaeta, Eunicidae), a redescription based on the holotype and Brazilian specimens
}

\author{
Tatiana Menchini Steiner ${ }^{1}$ \\ João M. de M. Nogueira ${ }^{2}$
}

A. Cecília Z. Amaral ${ }^{1}$

\begin{abstract}
Based on features of the holotype and seven Brazilian specimens examined under stereomicroscope, light microscope, and scanning electron microscope, Eunice rubra Grube, 1856 is redescribed, allowing for intraspecific variation and providing information on characters not included in a previous redescription. Characters important for the taxonomy of the genus varied widely, although in some cases because of fixation artefacts.

KEY WORDS. Eunice rubra, Eunicidae, Polychaeta, taxonomy, south-eastern Brazil
\end{abstract}

FAUCHALD (1992) based his revision of Eunice Cuvier, 1817 upon type material, some of which consisted of poorly preserved specimens, few or single individuals, or individuals with missing parts. Because of this, in several species certain characters were scored as unknown, and intraspecific variation was impossible or nearly impossible to evaluate. Eunice rubra Grube, 1856 is a good example. FAUCHALD (1992) examined only the holotype, which was incomplete, and therefore characters such as maxillary formulae, total length, and the morphology of the posterior end were impossible to describe precisely.

In Brazil, four specimens of a species which was previously considered as new and close to E. rubra, were collected in a sandy beach and in living colonies of the coral Mussismilia hispida (Verrill, 1868). In order to define the differences between our specimens and Eunice rubra, which has been reported several times from the Brazilian coast (NONATO \& LUNA 1970; MORGADO \& AMARAL 1981; DUARTE \& NALESSO 1996), three specimens of the latter from the collection of Dr. Edmundo Ferraz Nonato were borrowed, and the holotype was also examined. The analysis indicated that the seven specimens from Brazil were actually E. rubra. Moreover, this species shows variation in characters considered important by FAUCHALD (1992) for the taxonomy of the genus, such as the shape of articulations in palps, antennae and peristomial cirri, the segment on which the branchiae first appear, and the number of branchial filaments per parapodium.

In the present paper, E. rubra is redescribed, based on a comprehensive morphological comparison of the holotype and the seven Brazilian specimens. The

1) Departamento de Zoologia, Instituto de Biologia, Universidade Estadual de Campinas. Caixa Postal 6109, 13083-970 Campinas, São Paulo, Brasil. E-mail: tatims @unicamp.br

2) Departamento de Zoologia, Instituto de Biociências, Universidade de São Paulo. Rua do Matão, Travessa 14, 101, 05508-900 São Paulo, Brasil. E-mail: nogueira@ib.usp.br 
identity of the taxon E. rubra is reinforced by discussion of the differences between it and the species considered by FAUCHALD (1992) as closest to it, in view of the new information presented herein.

\section{MATERIAL AND METHODS}

The Brazilian material was collected on the northern coast of the State of São Paulo, south-eastern Brazil. Three specimens (numbers 1, 2, and 4) came from two independent projects. The first project analysed macrofaunal polychaetes from intertidal sandy beaches along São Sebastião Channel, and the second project examined the polychaetes living on tufts of algae and colonies of the coral Mussismilia hispida at Alcatrazes Island. For the first project, samples of sediment were collected between 1995 and 1997 at São Francisco Beach, and the polychaetes were fixed in $70 \%$ ethanol. The collections from Alcatrazes Island were made in 1995; the material was fixed in formalin, corals were de-calcified with formalin-formic acid solution, and the polychaetes were sorted and preserved in $70 \%$ ethanol.

Three additional specimens (fixed in formalin and preserved in $70 \%$ ethanol) from Ubatuba were borrowed from the collection of Dr. Edmundo F. Nonato. One specimen from the same beach as specimens 1 and 2 (fixation method unknown) was kindly provided by a colleague.

The specimens were inspected under a stereomicroscope. Slides permanently mounted in glycerin jelly were analysed under a light microscopy. Drawings were made with the aid of a drawing tube. For scanning electron microscope (SEM - Model JEOL JSM5800LV), several parapodia were detached, critical-point-dried, and covered with $40 \mathrm{~nm}$ of gold.

The holotype is deposited in the Zoological Museum, University of Copenhagen, Copenhagen, Denmark. The Brazilian material is deposited in the polychaete collection (MHN-BPO-ST) of the Museu de História Natural, State University of Campinas, state of São Paulo, Brazil.

\section{RESULTS}

\section{Eunice Cuvier, 1817} (1900).

Type Species. Leodice gigantea Lamarck, 1818, designated by VERRILL

According to ORRHAGE (1995), Eunice is characterised by having one central antenna, one pair of lateral antennae, one pair of slender dorsolateral palps (formerly considered as an additional pair of antennae), and one pair of peristomial cirri. Setae include limbate, pectinate, compound falcigers, subacicular hooks, and, in some species, compound spinigers and pseudocompound falcigers; subacicular hooks and falcigers are protected by paired guards (FAUCHALD 1992). Branchiae may be present; some species have been described based on specimens with or without branchiae and, although FAUCHALD (1992) contests both morphs belonging to the same species, NOGUEIRA et al. (2001) demonstrated that, at least for E. insularis Nogueira, Steiner \& Amaral, 2001, branchiate and abranchiate forms do exist. 


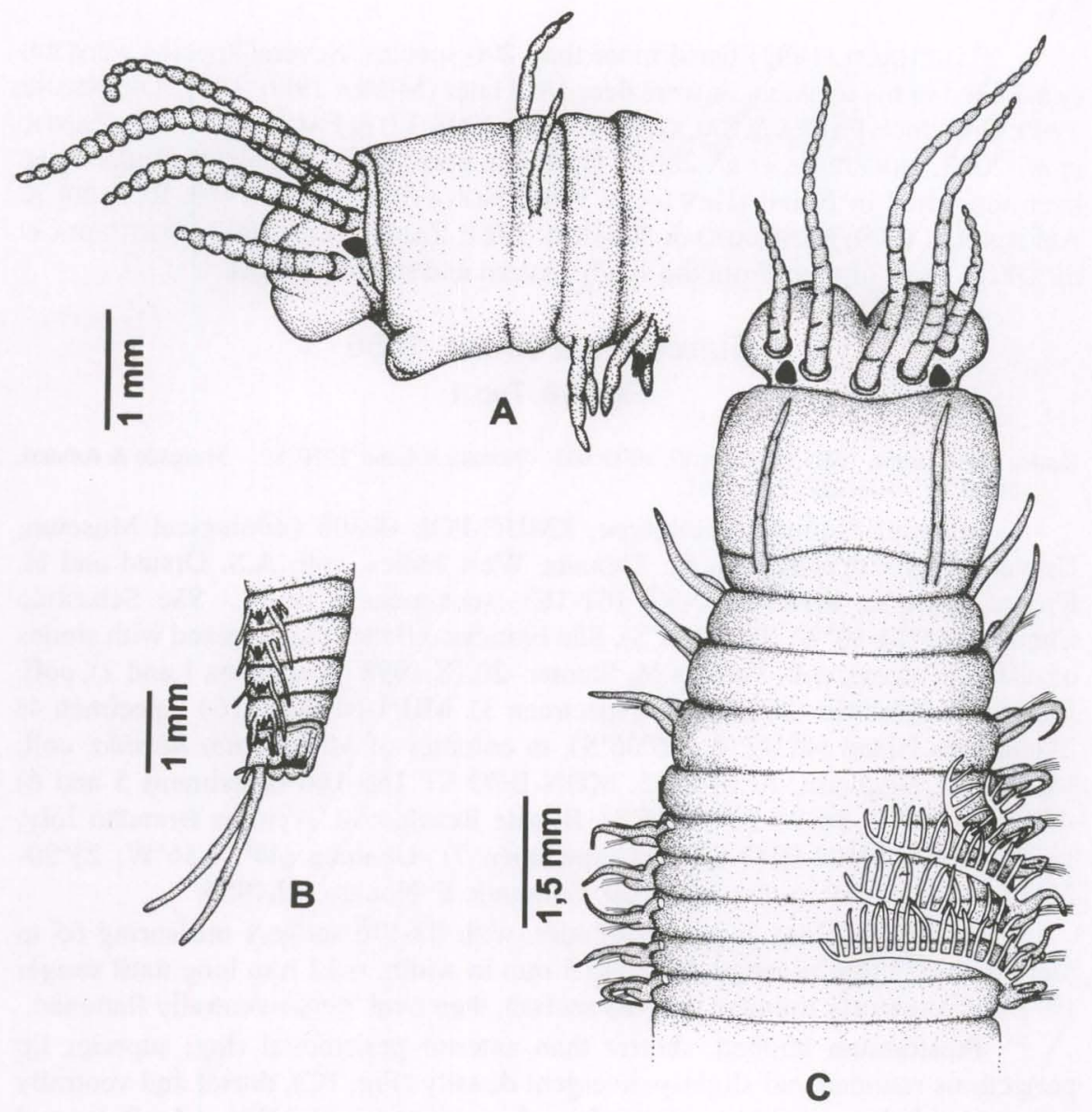

Fig. 1. Eunice rubra. (A) anterior body, lateral view; (B) pygidium; (C) anterior body, dorsal view. (A) specimen 6, (B-C) specimen 1.

$=6-8+7-10, \mathrm{MV}=1+1$; left MIV with large teeth on the external side, and short teeth or even inconspicuous indentations, on internal side. From setiger 1, segments similar in length, progressively widening until setiger 10 (Fig. 1C). Peristomial cirri thin, slightly inflated basally, with 4-8 articles varying from weakly articulated cylinders to moniliform, distally tapering, reaching to or close to the anterior border of peristomium; basal article always longer than remaining articles.

Dorsal cirri with 4-8 true articles (Fig. 1A) or nearly smooth (3-4 constrictions) (Fig. 1C) along the entire body (degree of segmentation varying among specimens) (Figs 1A-C, 2A-D, 6A, 6C), about twice as long as ventral cirri; stout on abranchiate setigers (Fig. 2A-B), becoming progressively shorter and thinner from setiger 5 (Fig. 2C-D). Ventral cirri longer than acicular lobules on all setigers, stout and digitiform until setiger 4-5 (Fig. 2A-B), then basally inflated with 
FAUCHALD (1992) listed more than 200 species. Several species were not considered in his revision, or were described later (MIURA 1986, 1987; ORENSANZ 1990; CARRERA-PARRA \& SALAZAR-VALEJO 1998; LU \& FAUCHALD 1998; ZANOL et al. 2000; NoGUEIRA et al. 2001). Up to the present, 37 species of Eunice have been identified in Brazil (HARTMAN 1948; NONATO \& LUNA 1970; RULLIER \& AMOUREUX 1979; MORGADO \& AMARAL 1981; ZANOL et al. 2000; NogueIRA et al. 2001), most of them from the south-eastern and southern areas.

\section{Eunice rubra Grube, 1856}

Figs 1-8, Tab. I

Eunice rubra Grube, 1856: 59. - Verrill, 1900: 603. - Nonato \& Luna, 1970: 81. - Morgado \& Amaral, 1981: 36. - Fauchald, 1992: 291.

Material examined. Holotype: ZMUC-POL 00308 (Zoological Museum, University of Copenhagen), St. Thomas, West Indies, coll. A.S. Örsted and H. Kröyer. BRAZIL: MHN-BPO-ST 161-163 (specimens 1 to 3) - São Sebastião

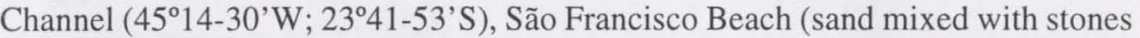
of different sizes), coll. Tatiana M. Steiner -20.IX.1998 (specimens 1 and 2), coll. Jolnnye R. Abrahão -20/05/2000 (specimen 3). MHN-BPO-ST 164 (specimen 4)

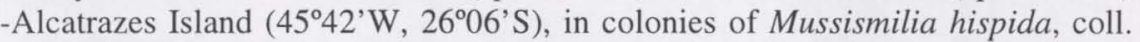
João M.M. Nogueira, 17.III.1995. MHN-BPO-ST 165-166 (specimens 5 and 6)

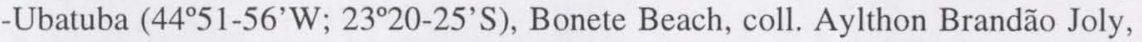
19.VIII.1963. MHN-BPO-ST 167 (specimen 7) -Ubatuba (4451-56'W; 232025 'S), inside empty oyster shell, coll. Edmundo F. Nonato, III.1959.

Diagnosis. Body long and slender, with 83-176 setigers measuring 65 to more than $177 \mathrm{~mm}$ in length by $2.5-5.5 \mathrm{~mm}$ in width, 6-12 $\mathrm{mm}$ long until setiger 10. Body anteriorly rounded in cross section, then oval, dorso-ventrally flattened.

Prostomium bilobed, shorter than anterior peristomial ring; superior lip projections rounded and slightly divergent distally (Fig. 1C), dorsal and ventrally inflated, with deep median ventral sulcus; lower lip muscular (Fig. 1A). Palps and antennae in horseshoe arrangement; ceratophores ring-shaped, without articulations. Styles basally wrinkled (Fig. 5A) or with one short cylindrical article (Fig. 5B-D); moniliform articles along most of their length, drop-shaped in distal third or on the last one or two articles. Moniliform articles with quadrate or rounded-quadrate margins. Palps with 8-13 articles, extending to posterior part of anterior peristomial ring; lateral antennae with 14-24 articles, reaching posterior part of setiger 1 to setiger 3; central antenna with 15-24 articles, reaching setiger 2 to setiger 4 ; longer specimens always showing the higher values for these variables. One pair of triangular eyes, with rounded edges between bases of palps and lateral antennae, varying from dark red to black.

Anterior peristomial ring about three times the length of posterior ring, in dorsal view; separation between rings visible dorsal and ventrally, not laterally. Mandibles brown, shorter than maxillae (Fig. 4A), hard, cutting edges with darker concentric lines, strongly marked, covered by one pair of white, hard calcareous pieces (easily dettached) (Fig. 4B). Maxillary formula: $\mathrm{I}=1+1, \mathrm{II}=5-6+5-8, \mathrm{MIII}=5-8+0, \mathrm{MIV}$ 

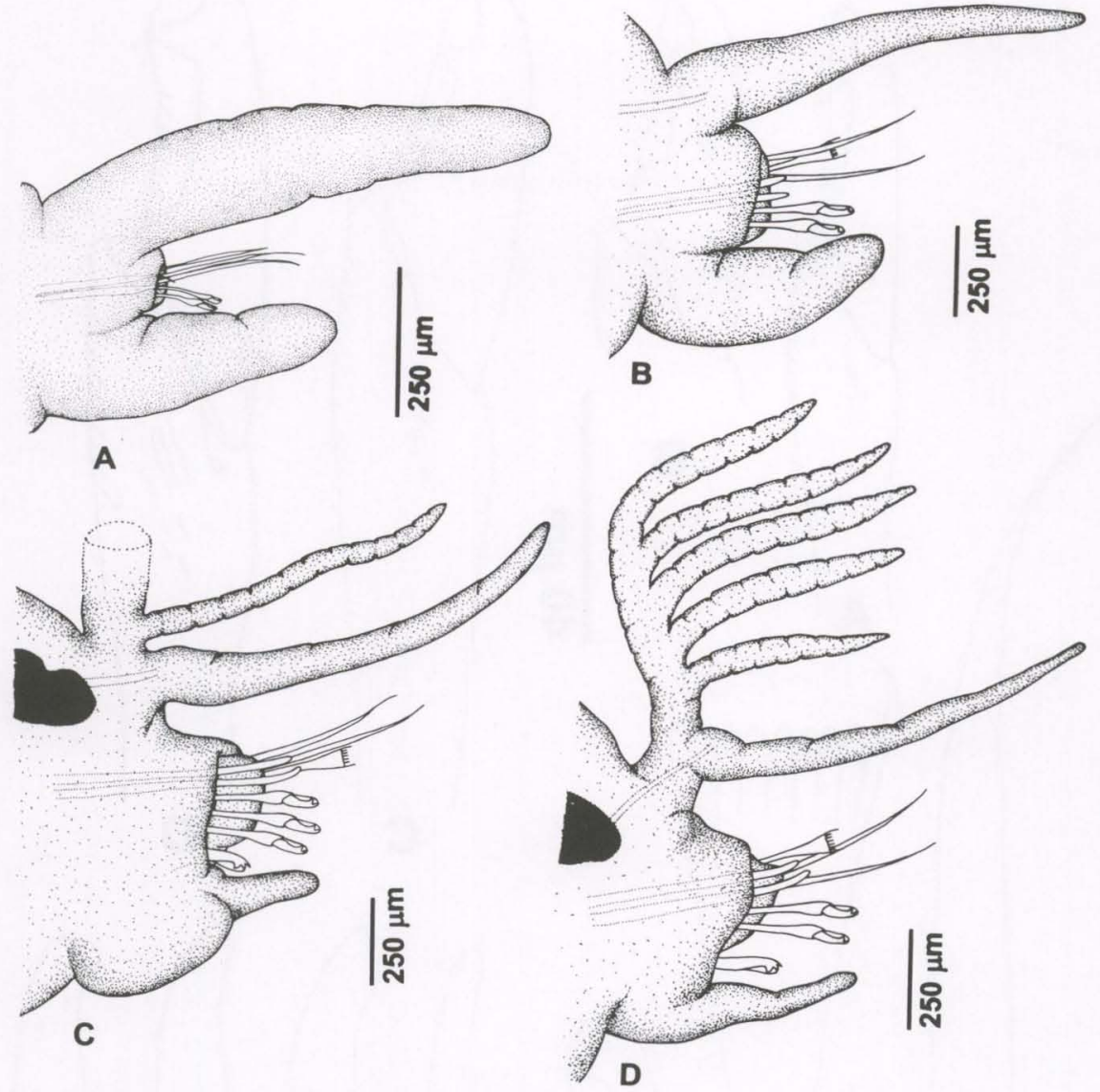

Fig. 2. Eunice rubra. (A) parapodium 1; (B) parapodium 4; (C) parapodium 25; (D) parapodium 74. (A) specimen 3 , (B-D) specimen 1.

digitiform round tips for a short extension (Figs 2C, 6A). Inflated bases progressively decreasing and disappearing around setiger 40-55, while tips of cirri become longer and thinner towards end of body (Figs 2D, 6C).

Branchiae pectinate, beginning on setiger 4-6, with few filaments in the first one or two parapodia; number of filaments progressively increasing until about 14-21, for a short extension, then decreasing again to 1-3 filaments until near the end of body (Fig. 8). Most specimens showing slight increase in number of filaments on posterior body. Branchial stem up to three times longer than dorsal cirrus (Fig. 1C); branchial filaments shorter, laterally ciliated (Fig. 6B). Branchiate setigers with one internal light brown to black spot per parapodium (faint in specimens 5,6 and 7), near origin of notoacicula (Fig. 2C-D). Posteriormost setigers abranchiate (Fig. 1B). 


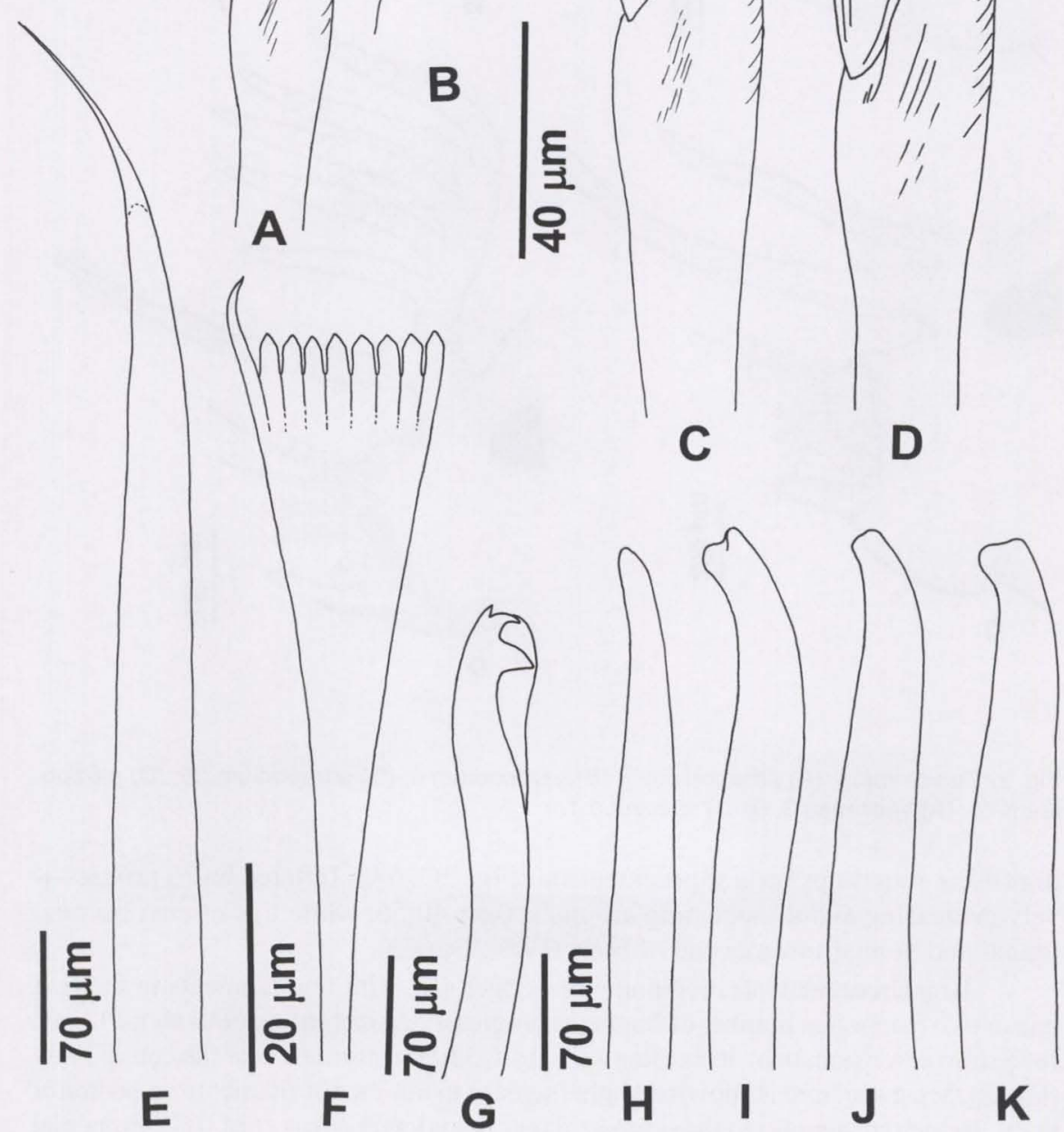

Fig. 3. Eunice rubra. (A-D) falcigers: $(A)$ setiger 1 ; $(B)$ setiger 2 ; $(C)$ setiger 14 ; $(D)$ setiger 118; $(\mathrm{E}, \mathrm{H}-\mathrm{K})$ acicula; $(F)$ pectinate setae; $(\mathrm{G})$ subacicular hook. (A- E) specimen 3 , (H-K) specimen 1. 

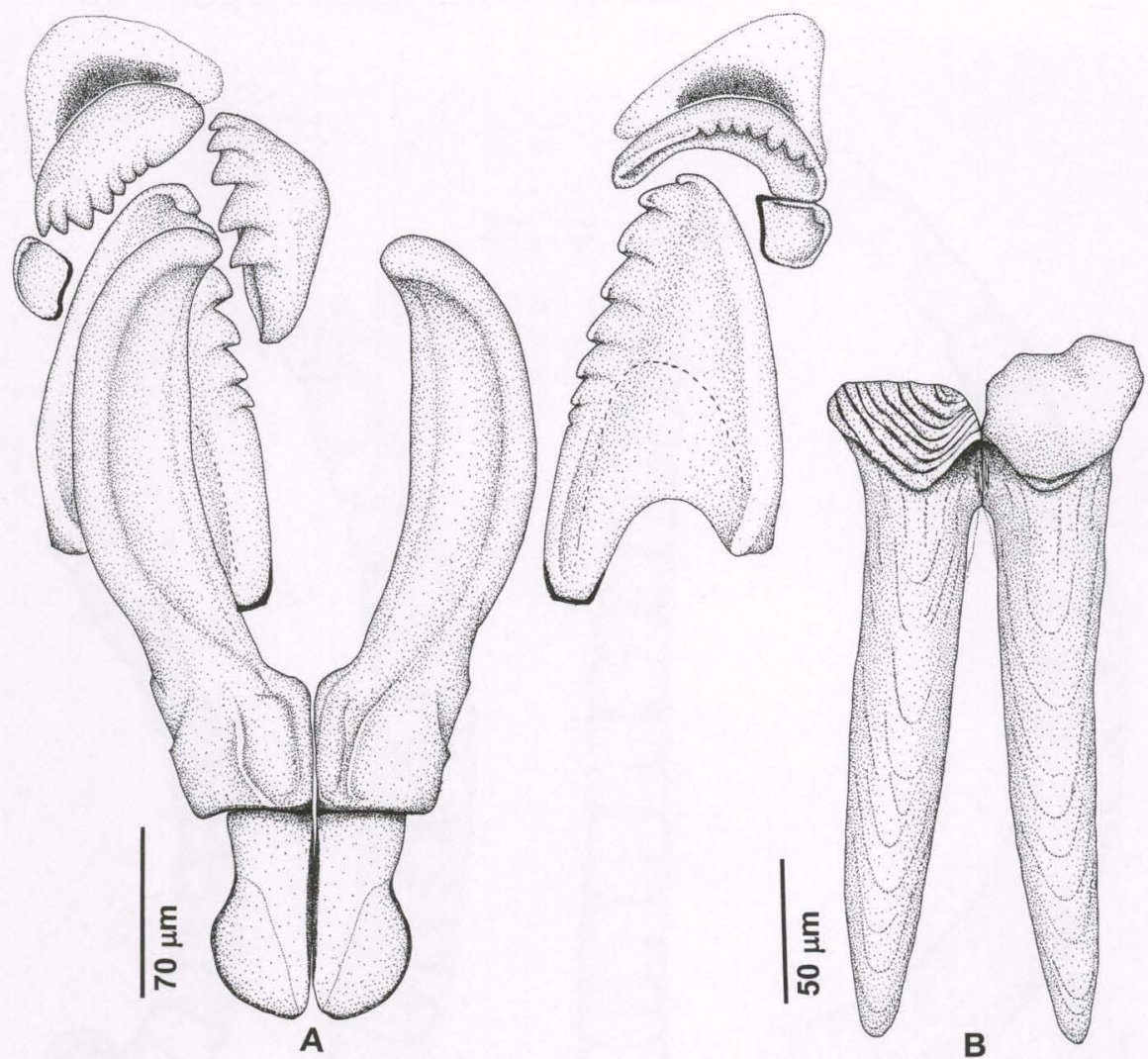

Fig. 4. Eunice rubra. Specimen 3. (A) maxillae, dorsal view; (B) mandibles, ventral view (left white calcareous pieces omitted).

Neuropodial acicular lobules rounded until midbody, conical on posterior setigers; pre- and post-setal lobules straight, shorter than the acicular lobules (Figs 2B-D, 6A, 6C). Supra-acicular bundle of setae from anterior setigers (Fig. 7B) including 6-12 limbate capillaries, thin, minutely denticulate laterally, central core smooth (Fig. 7A, 7D) and up to 10 pectinate setae, straight, with denticulate shaft, 8-11 sharp teeth, one lateral tooth longer than the remaining teeth (Figs 3F, 7D). Infra-acicular bundle of setae including bidentate compound falcigers (Fig. 7A) with paired guards, without mucros, denticulate basally and surrounding the blades like covers (Fig. 7C, 7E); blades bidentate, teeth distally blunt, proximal tooth triangular, laterally directed, shorter than distal tooth on anterior setigers (Fig. 3A-B), progressively increasing in length and becoming larger than distal tooth from midbody to pigydium (Fig. 3C-D); distal tooth directed laterally to obliquely upwards. Number of setae decreasing towards end of body. Subacicular hook light yellow, present from setiger 22-33, tridentate with teeth in a crest (Figs 3G, 6D), distal tooth reduced, directed obliquely upwards, remaining teeth directed laterally, inferior tooth larger; most specimens with one hook per 


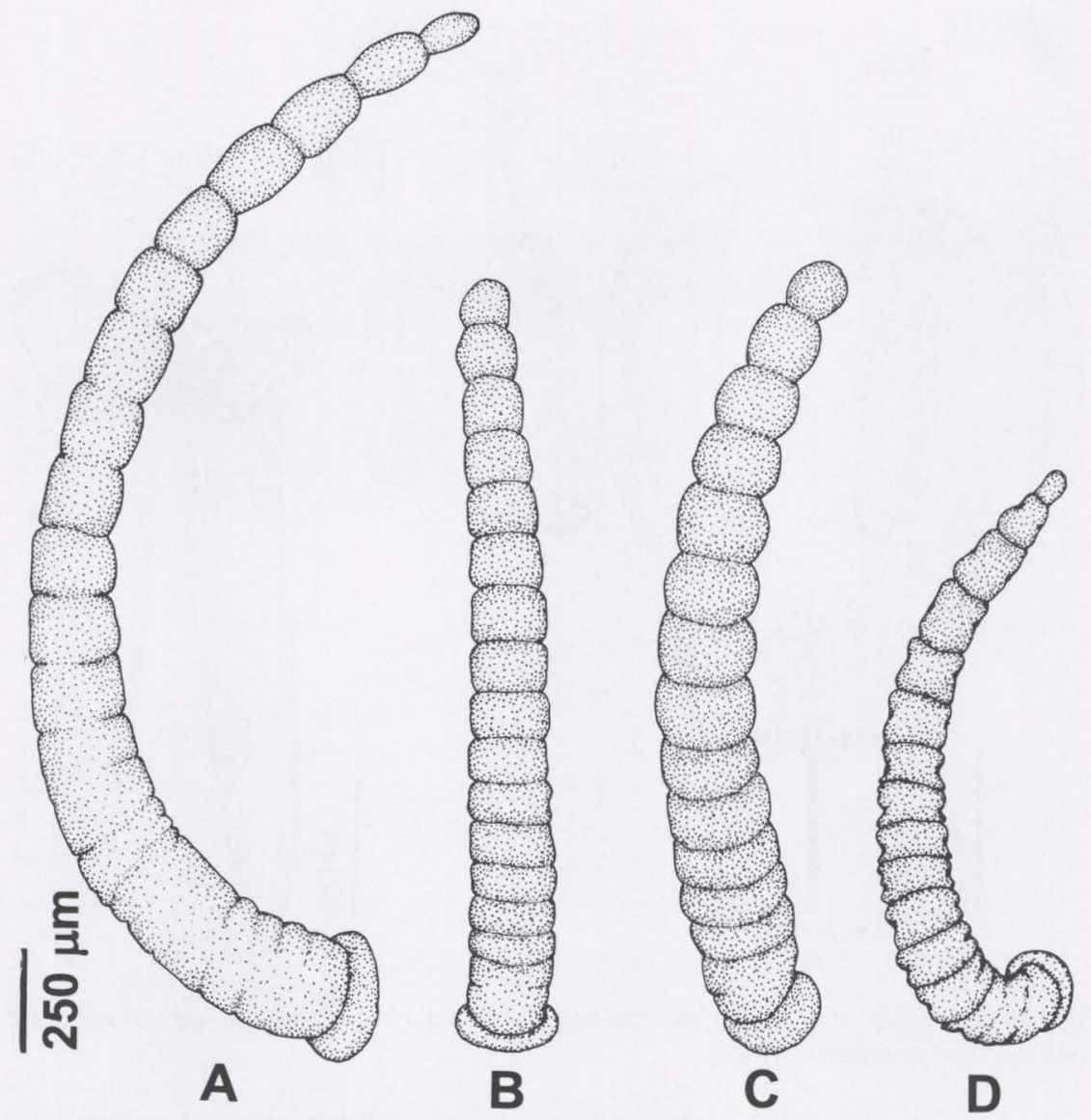

Fig. 5. Eunice rubra. Ceratophore and style of lateral antenna. (A) specimen 1, (B) specimen 4, (C) specimen 6, (D) specimen 3.

parapodium, except for replacements. Holotype and specimen 3 with two hooks on many setigers. Acicula prominent, light yellow, usually two per parapodium. On anterior setigers, acicula gently tapering to blunt tips, slightly bent distally (Fig. 3H and J); from midbody, acicula more conspicuosly bent, usually with two stout blunt teeth (Fig. 3I and K). Anteriormost setigers with additional aciculum gently tapering to long filiform tip (Fig. 3E).

Pygidium with two pairs of anal cirri, superior pair long, subulate, smooth to irregularly wrinkled, inferior pair thin and much shorter, about $1 / 15$ length of superior cirri (Fig. 1G). 

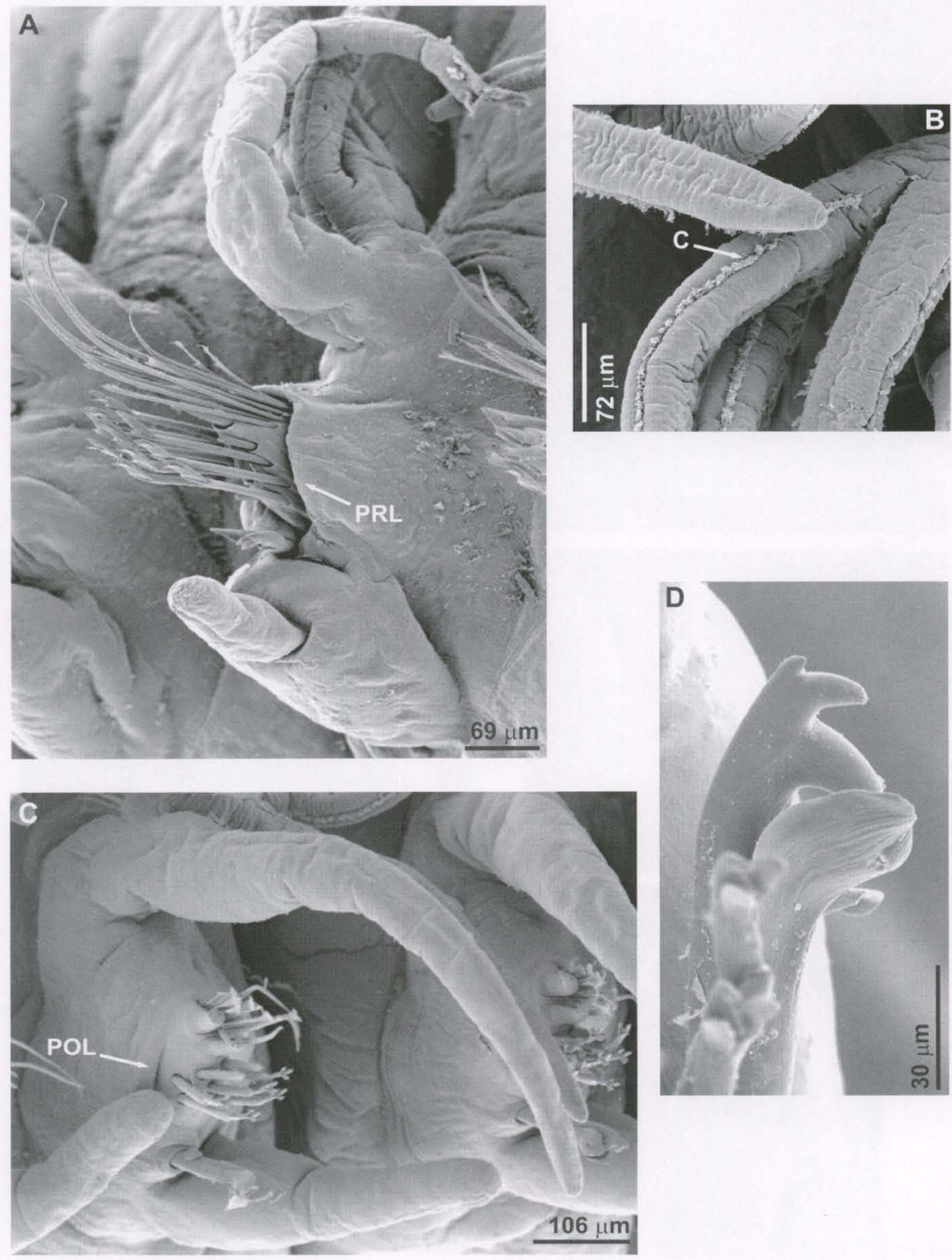

Fig. 6. Eunice rubra. Specimen 2. (A) parapodium 28; (B) detail of branchiae; (C) parapodium 107; (D) subacicular hook. C - cillia, POL - post-setal lobule, PRL - pre-setal lobule. 

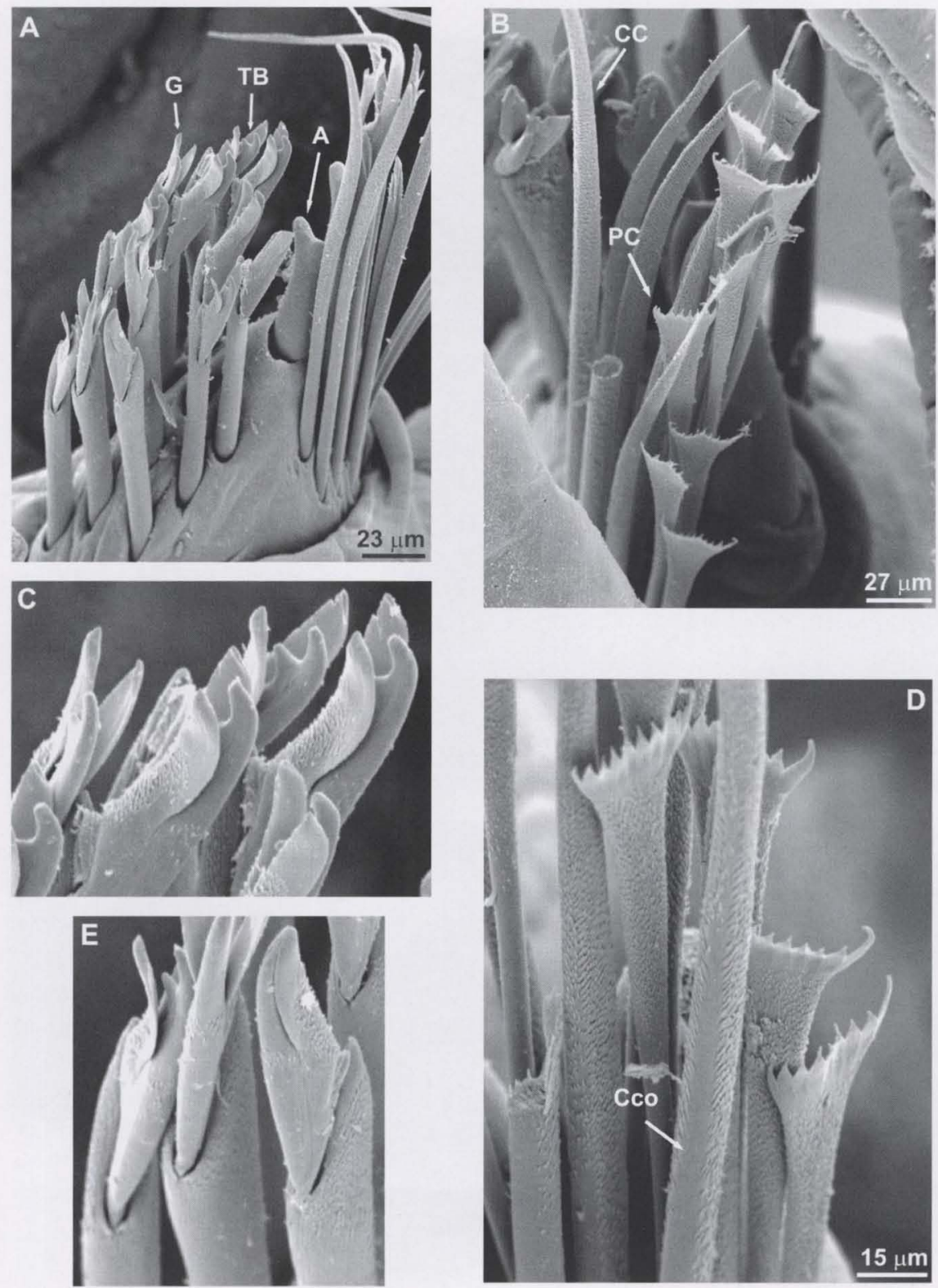

$5 \mu \mathrm{m}$

Fig. 7. Eunice rubra. specimen 2. (A) setae, parapodium 29; (B) supracicular setae; (C) and (E) details of the blades of falcigers; (D) detail of supracicular seta. CC - capillary setae, A - Aciculum, Cco - central core of capillary setae, G - guards, PC - pectinate setae, TB teeth of the blade. 


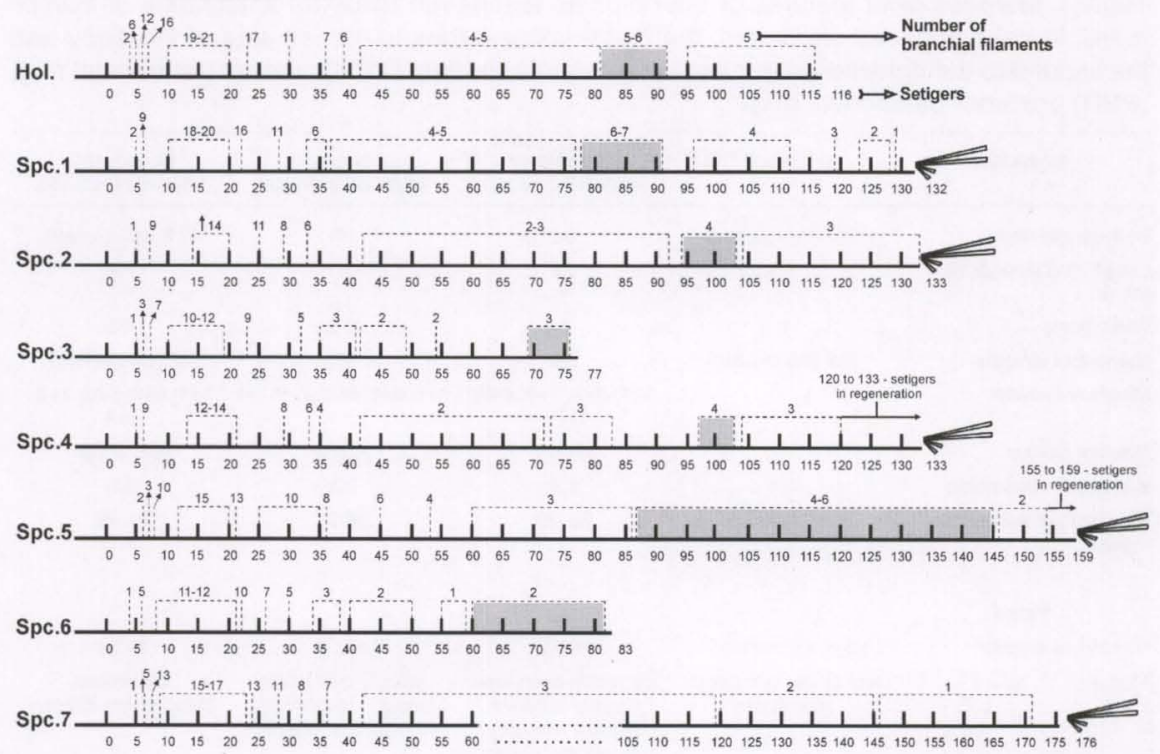

Anterior end

Posterior end

Fig. 8. Eunice rubra. Branchial formulae of all specimens examined, showing the increasing number of filaments in the posterior part of the body (darker area). Hol. - holotype, Spc. specimen.

\section{Holotype}

Based on examination of the single type specimen, certain characters of the species must be reevaluated.

The holotype is well preserved, although it seems dehydrated, with the cuticule wrinkled and folded, altering the length and width of the body. Its original width may have been over $3 \mathrm{~mm}$.

The distal end of the prostomium is damaged, somewhat altering its original morphology. The peristomial cirri are also damaged. The left cirrus reaches setiger 3 and has an inflated base and pointed tip. On the proximal half of the cirrus, 3 constrictions are well marked and the distal half is clearly smooth. The right cirrus is short and incomplete.

The dorsal cirri of anterior setigers are articulated, as described by FAUCHALD (1992). The posterior cirri are irregularly wrinkled, rather than divided into 3-4 articles. Several types of articles form the central antenna: the first is a short cylinder, the following articles are moniliform, next it has subquadrate cylinders, as in the specimen 3 (Fig. 5D), ending with drop-shaped articles, as in the specimen 1 (Fig. 5A). Other characters accord well with the description presented above. 
Table I. Morphological features of the holotype and seven Brazilian specimens of Eunice rubra. In case of paired structures, the first number reffers to the left side of the body and the second to the right side; (-) means missing information; (APR) anterior peristomial ring, (PPR) posterior peristomial ring.

\begin{tabular}{|c|c|c|c|c|}
\hline Character & Holotype & $\begin{array}{c}\text { Specimen } 1 \\
\text { MHN-BPO-ST161 }\end{array}$ & $\begin{array}{c}\text { Specimen } 2 \\
\text { MHN-BPO-ST162 }\end{array}$ & $\begin{array}{c}\text { Specimen } 3 \\
\text { MHN-BPO-ST163 }\end{array}$ \\
\hline Body length (mm) & 177 (incomplete) & 80 & 65 & 47.8 (incomplete) \\
\hline $\begin{array}{l}\text { Length to chaetiger } 10 \\
(\mathrm{~mm})\end{array}$ & 7.5 & 8.2 & 6 & 7.2 \\
\hline Width $(\mathrm{mm})$ & 3 & 5 & 2.5 & 4.5 \\
\hline Number of setigers & 116 (incomplete) & 132 & 133 & 77 (incomplete) \\
\hline Maxillary formula & - & $\begin{array}{c}1+1 ; 6+7 ; 7+0 ; 6+8 \\
1+1\end{array}$ & $1+1 ; 6+8 ; 8+0 ; 7+9 ; 1+1$ & $\begin{array}{c}1+1 ; 6+8 ; 5+0 ; 7+7 \\
1+1\end{array}$ \\
\hline Maxillae Colour & - & brown & yellow & light brown \\
\hline Branchiae - Beginning & 4.4 & 5.5 & 5.5 & 5.5 \\
\hline $\begin{array}{l}\text { Beginning of subacicular } \\
\text { hooks }\end{array}$ & 24,24 & 25,23 & 24,24 & 24,22 \\
\hline \multicolumn{5}{|l|}{ Palps } \\
\hline Number of articles & 3,5 , incomplete & 9,11 & 10,8 & 9,10 \\
\hline Shape & $\begin{array}{c}\text { first article cylindrical; } \\
\text { moniliform }\end{array}$ & $\begin{array}{l}\text { first article cylindrical; } \\
\text { basally wrinkled; } \\
\text { median = weakly } \\
\text { moniliform; distaly } \\
\text { drop-shaped }\end{array}$ & $\begin{array}{l}\text { basally-cylindrical } \\
\text { median-moniliform } \\
\text { distally-drop-shaped }\end{array}$ & $\begin{array}{c}\text { moniliform } \\
\text { distally-drop-shaped }\end{array}$ \\
\hline Extension & & end of APR & end of APR & posterior APR \\
\hline \multicolumn{5}{|l|}{ Lateral antennae } \\
\hline Number of articles & 14,6 & 19,21 & 15,15 &,- 16 \\
\hline Shape & same as palps & same as palps & same as palps & same as palps \\
\hline Extension & setiger 1 & setiger 2 & setiger 2 & setiger 2 \\
\hline \multicolumn{5}{|l|}{ Central Antenna } \\
\hline Number of articles & 21 (almost complete) & 24 & 15 & - \\
\hline Shape & $\begin{array}{l}\text { first article cylindrical; } \\
\text { basally moniliform } \\
\text { median = short } \\
\text { cylinders } \\
\text { distally - drop shaped }\end{array}$ & same as palps & same as palps & - \\
\hline Extension & setiger 3 & setiger 4 & half of setiger 2 & - \\
\hline \multicolumn{5}{|l|}{ Peristomial cirri } \\
\hline Number of articles & (?) $3,-$ & 4,4 & 4,4 & 5,5 \\
\hline Shape & segmentation faint & segmentation faint & $\begin{array}{l}\text { segmentation faint } \\
\text { (left), cylindrical (right) }\end{array}$ & segmentation faint \\
\hline Extension & half APR & end of APR & beginning of APR & beginning of APR \\
\hline \multicolumn{5}{|l|}{ Ventral cirri } \\
\hline Digitiform between setigers & $1-3$ & $1-3$ & $1-4$ & $1-3$ \\
\hline $\begin{array}{l}\text { Inflated bases between } \\
\text { setigers }\end{array}$ & 4-34 & 4-34 & $5-26$ & 4-35 \\
\hline $\begin{array}{l}\text { Inflated bases decreasing } \\
\text { between setigers }\end{array}$ & $35-43$ & $36-55$ & $27-43$ & $36-46$ \\
\hline Filiform between setigers & $44-116$ & $56-132$ & $44-133$ & 47-end (fragment) \\
\hline
\end{tabular}


Table I. Continued.

\begin{tabular}{|c|c|c|c|c|}
\hline Character & $\begin{array}{c}\text { Specimen } 4 \\
\text { MHN-BPO-ST164 }\end{array}$ & $\begin{array}{c}\text { Specimen } 5 \\
\text { MHN-BPO-ST165 }\end{array}$ & $\begin{array}{c}\text { Specimen } 6 \\
\text { MHN-BPO-ST166 }\end{array}$ & $\begin{array}{c}\text { Specimen } 7 \\
\text { MHN-BPO-ST167 }\end{array}$ \\
\hline Body length (mm) & 70 & 153 & 49.5 (incomplete) & 133 \\
\hline $\begin{array}{l}\text { Length to chaetiger } 10 \\
(\mathrm{~mm})\end{array}$ & 7 & 12 & 7.5 & 10 \\
\hline Width (mm) & 4.5 & 5.5 & 4 & 5 \\
\hline Number of setigers & $\begin{array}{l}\text { 133, regenerating from } \\
\text { setiger } 121\end{array}$ & $\begin{array}{l}\text { 159, regenerating from } \\
\text { setiger } 155\end{array}$ & 83 (incomplete) & 176 \\
\hline Maxillary formula & $\begin{array}{c}1+1 ; 5+8 ; 7+0 ; 8+10 \\
1+1\end{array}$ & - & - & $\begin{array}{c}1+1 ; 6+5 ; 7+0 ; 7+8 ; \\
1+1\end{array}$ \\
\hline Maxillae Colour & light brown & - & - & light brown \\
\hline Branchiae - Beginning & 5.5 & 5.6 & 4.4 & 5.5 \\
\hline $\begin{array}{l}\text { Beginning of subacicular } \\
\text { hooks }\end{array}$ & 24,24 & 29,33 & 22,22 & 23,24 \\
\hline \multicolumn{5}{|l|}{ Palps } \\
\hline Number of articles & 10,8 & 12,12 , incomplete & 8,9 & 12,13 \\
\hline Shape & $\begin{array}{c}\text { moniliform } \\
\text { distally-drop-shaped }\end{array}$ & moniliform & $\begin{array}{c}\text { moniliform } \\
\text { distally-drop-shaped }\end{array}$ & $\begin{array}{c}\text { moniliform } \\
\text { distally-drop-shaped }\end{array}$ \\
\hline Extension & end of APR & - & posterior APR & end of APR \\
\hline \multicolumn{5}{|l|}{ Lateral antennae } \\
\hline Number of articles & 14,14 & 24,17 , incomplete & 14,18 & $21,-$ \\
\hline Shape & $\begin{array}{c}\text { moniliform } \\
\text { distally-drop-shaped }\end{array}$ & moniliform & $\begin{array}{c}\text { moniliform } \\
\text { distally-drop-shaped }\end{array}$ & $\begin{array}{c}\text { moniliform } \\
\text { distally-drop-shaped }\end{array}$ \\
\hline Extension & setiger 2 & - & end of set iger 1 & half setiger 3 \\
\hline \multicolumn{5}{|l|}{ Central Antenna } \\
\hline Number of articles & 16 , incomplete & 11 , incomplete & 20 & 10 , incomplete \\
\hline Shape & moniliform & moniliform & moniliform & moniliform \\
\hline Extension & - & - & setiger 2 & - \\
\hline \multicolumn{5}{|l|}{ Peristomial cirri } \\
\hline Number of articles & 6,6 & 5,5 & 5,5 & 6,6 \\
\hline Shape & moniliform & segmentation faint & $\begin{array}{c}\text { cylindrical; } \\
\text { drop-shaped distally }\end{array}$ & segmentation faint \\
\hline Extension & beginning of APR & anterior APR & beginning of APR & beginning of APR \\
\hline \multicolumn{5}{|l|}{ Ventral cirri } \\
\hline Digitiform between setigers & $1-3$ & $1-3$ & $1-3$ & 1.4 \\
\hline $\begin{array}{l}\text { Inflated bases between } \\
\text { setigers }\end{array}$ & $4-31$ & $4-34$ & $4-30$ & $5-34$ \\
\hline $\begin{array}{l}\text { Inflated bases decreasing } \\
\text { between setigers }\end{array}$ & $32-45$ & $35-54$ & $31-40$ & $35-57$ \\
\hline Filiform between setigers & $46-133$ & 55-159 & 41-end (fragment) & $58-176$ \\
\hline
\end{tabular}




\section{DISCUSSION}

Table I lists the morphological features of holotype and all other specimens examined.

FAUCHALD (1992) placed great value on the articulations of the palps and antennae, whether they are moniliform or cylindrical, and used this character to separate groups of species. According to his concept, a moniliform articulation may vary from drop-shaped through rounded-quadrangular, to nearly triangular. According to the identification key provided by FAUCHALD (1992), E. rubra falls within a group of species having only moniliform articulations, rather than moniliform but drop-shaped distally.

Based on features of holotype and the seven specimens observed in the present study, this character shows some variation, since styles and peristomial cirri with very faint articulations (mainly specimen 1 ) and strongly moniliform (specimens 2, 4, and 7) were equally seen. The shape of the moniliform articles also varied from quadrangular (Fig. 5A, B), rounded-quadrangular (Fig. 5C), to drop-shaped (distally, in complete styles). Specimen 3 seems to be dehydrated like the holotype; therefore, although still moniliform, the articles of the antennae and palps appear deformed (Fig. 5D). Dorsal cirri also varied from nearly smooth, with very faint segmentation (such as in specimen 1), to truly articulated, with up to eight articles (as in specimen 5, 6, and 7, which has up to eight articles, even on posterior body).

The variation observed in the morphology of the articles of antennae, palps, and peristomial and dorsal cirri is probably related to the fixation and preservation of the specimens. The holotype and specimen 3 both appear dehydrated (specimen 3 more than the holotype), and have quadrate, centrally depressed articles (Fig. 5D). On the other hand, specimen 4 also has quadrate articles, but they are not depressed (Fig. 5B), and this specimen shows no evidence of dehydration. Specimens 5-7 have rounded quadrate articles up to the last third, after which they are drop-shaped (Fig. 5C). In specimen 1, the peristomial appendages are wrinkled at the base (Fig. 5A). We concluded that fixation and preservation seem to affect the morphology of soft structures, some of which were considered important by FAUCHALD (1992) for the taxonomy of the genus.

Other characters, such as the number of branchial filaments, the number of articles in the antennae and palps, the maxillary formula, and the number of hooks per parapodium also varied among the specimens. These variations appeared not to depend on the size of the specimens..

The total number of branchial filaments was highly variable among the specimens. This number increased slightly on the posterior segments of most specimens, but not in specimen 7 (Fig. 8). The length of filaments varied from about the same length as the dorsal cirri along the entire body, in some specimens, to distinctly longer than dorsal cirri, increasing posteriorly, in holotype and other specimens.

The eversible jaw apparatus is flexible, mainly in specimen 2 . Specimen 1 differs in having this apparatus darker and harder, with a central subquadrate sclerotinised tissue on the roof of the mouth, near MIV. The variation in maxillary formula was remarkable, the specimens had different numbers of teeth on maxillae II, III and IV (Tab. I). Nevertheless, some patterns seem to be characteristic: maxilla

Revta bras. Zool. 19 (Supl. 1): $243-259,2002$ 
II has fewer teeth on the left side than on the right; maxilla III has large, sharply pointed teeth; the external half of the left maxilla IV has large teeth, while in the internal half teeth are shorter, or even with indistinct indentations; right maxilla IV has all teeth nearly the same size.

The numbers of anterior setigers with ventral cirri with inflated bases, and of posterior setigers with filiform-tipped cirri are size-dependent, because both areas are more developed in longer specimens.

The beginning of the branchiae and the subacicular hooks also seemed to be size-dependent, because specimen 5 (the longest animal) had both structures appearing more posteriorly. Additional smaller specimens, however, are needed to verify this patern.

The morphology of the mandibular apparatus, eyes, parapodial lobules, falcigerous and pectinate setae is constant in all specimens.

Intraspecific variation seems to be considerable in this genus, at least for some species. NOGUEIRA et al. (2001) recently described two new species of Eunice from the coast of the State of São Paulo, one of which has branchiate and abranchiate forms, and branchiate specimens have branchial filaments varying in position and length. Moreover, NogUEIRA et al. (2001) demonstrated that juveniles of the same species frequently lack peristomial cirri, a situation which also occurs in $E$. wui $\mathrm{Lu}$ $\&$ Fauchald, 1998. This feature would have resulted in assignation of these specimens to the genus Paramarphysa Ehlers, 1887, if intraspecific variation and developmental characters had not been recognised.

In view of the new information provided by the present redescription, the differences between $E$. rubra and the closest species require re-evaluation. The species most similar to E. rubra are: E. lucei Grube, 1856, E. aequabilis Grube, 1878, E. martensi Grube, 1878, E. stigmatura (Verrill, 1900), E. panamena (Chamberlin, 1919), E. aedificatrix (Monro, 1933), and E. hirschi Fauchald, 1992. All the following comparisons were based on the redescription of these species by FAUCHALD (1992), and the original description, in the case of E. hirschi.

Eunice luce $i$ has up to eight branchial filaments, and acicula more distinctly hammer-head or bifid, with more prominent teeth. The falcigerous setae have the proximal tooth shorter than distal tooth along the entire body. The guards of falcigers have short mucros on the anterior setigers, while in E. rubra all guards lack mucros and proximal tooth is larger from the midbody posteriorly.

The holotype of $E$. martens $i$ is poorly preserved and, according to FAUCHALD (1992) several features are impossible to ascertain. The specimen, measuring 220 $\mathrm{mm}$ and having 168 setigers, has up to ten articles in lateral antennae (the only complete in holotype), the falcigerous setae are tridentate, and the acicula are more strongly bent and distally pointed, while E. rubra has more articles in the lateral antennae, and bidentate falcigers.

Eunice aequabilis has 12-17 branchial filaments on all setigers, while all specimens of $E$. rubra observed present anterior and posterior branchiate setigers with much fewer filaments. Besides, the blades of falcigers are tridentate in $E$. aequabilis, and bidentate in E. rubra. 
Eunice stigmatura has much longer antennae and palps, since the palps reach setiger 1 , the lateral antennae reach setiger 8 , and the central antenna reaches setiger 10. Moreover, E. stigmatura has dorsal cirri longer than the branchial stem on all setigers, pectinate setae narrower, with 5-6 teeth and one lateral tooth about twice as long and stout as the other teeth. This species tapers abruptly distally, and has falcigers with the proximal tooth about the same length as the distal tooth. The subacicular hook is bidentate and tridentate.

The holotype of Eunice panamena is an incomplete fragment $30 \mathrm{~mm}$ long, with 71 setigers. Its general appearance is rather different from $E$. rubra, since it has dark patches scattered over its anterior dorsum. The palps and antennae are moniliform and shorter: the palps reach the middle of the anterior peristomial ring, and lateral and central antennae reach setiger 1 . The branchiae have at most eight filaments. Moreover, E. panamena has falcigers with proximal tooth much shorter than distal tooth, which is nearly erect.

Eunice aedificatrix has shorter palps and antennae: the palps reach the middle of the anterior peristomial ring, the lateral antennae reach the posterior edge of the posterior peristomial ring, and the central antennae reach the middle of setiger 1 . The peristomial cirri are longer, extending to the middle of the prostomium. Furthermore, in E. aedificatrix the branchiae have no more than 11 filaments, the falcigers have the distal tooth longer than the proximal tooth, the acicula are distinctly hammer-head, and the subacicular hooks begin from setiger 35 .

Finally, E. hirschi has palps and antennae longer than E. rubra, since its palps extend to setiger 1 , the lateral antennae to setiger 3 , and central antenna to setiger 6. Moreover, E. hirschi has branchiae distinctly shorter than dorsal cirri, with 1-7 branchial filaments, and acicula bluntly pointed distally.

ACKNOWLEDGEMENTS. We express our gratitude to the Fundação de Amparo à Pesquisa do Estado de São Paulo (FAPESP) and the Conselho Nacional de Desenvolvimento Científico e Tecnológico (CNPq) for financial support; to the Departamento de Zoologia, IB, UNICAMP and the Centro de Biologia Marinha of the Universidade de São Paulo (CEBIMar) for the technical support; to the faculty of the Postgraduation Course of the Departamento de Zoologia, IB, USP, namely Drs Erika Schlenz and Fábio Lang da Silveira; to Prof. Danny Eibye-Jacobsen, curator of the Polychaete Collection of the Zoological Museum, University of Copenhagen, for lending us the holotype and for hosting us during our stay at the ZMUC; to Dr. Fausto Pires de Campos, for assistance with collecting at Alcatrazes; to Dr. Edmundo Ferraz Nonato for donating specimens 5, 6 and 7; to Jolnnye Rodrigues Abrahão for donating the specimen 3; to Dr. Sérgio A. Vanin (IB, USP) for his comments; and to Dr. Ismael Gioia (IB, UNICAMP) for lending us his drawing tube. Janet Reid revised the English text.

\section{REFERENCES}

Carrera-Parra, L.F. \& S.I. Salazar-Valejo. 1998. A new genus and 12 new species of Eunicidae (Polychaeta) from the Caribbean Sea. Jour. Mar. Biol. Ass. U.K. 78: 145-182.

DUARTE, L.F.L. \& R.C. NALESSO. 1996. The sponge Zygomicale parishii (Bowerbank) and its endobiotic fauna. Estuar. Coast. Shelf Sci. 42: 139-151.

Revta bras. Zool. 19 (Supl. 1): $243-259,2002$ 
Fauchald, K. 1992. A review of the genus Eunice based upon type material. Smithson. Contrib. Zool. 523: $1-421$.

GRUBE, A.E. 1856. Annulata Öerstediana. Enumeratio annulatorum, quae in itinere per Indian occidentalem et American centralem annis 845-848 suscepto legit. D.A.S. Öersted, adjectis specibus nonnullis a D.H. Kröeyer in itinere ad Americam meridionalem collectis. Dansk Naturh. Foren. Videns. Medd. 857: 158-86.

HARTMAN, O. 1948. The marine annelids erected by Kinberg, with some notes on some other types in the Swedish State Museum. Ark. Zool. Stockholm 42 (1): 1-137.

Lu, H. \& K. FAUChaLD. 1998. Description of Eunice weintraubi and E. wui, two new species of eunicid polychaetes from northern Gulf of Mexico. Proc. Biol. Soc. Wash. 111 (1): 230-240.

MiURA, T. 1986. Japanese polychaetes of the genera Eunice and Euniphysa: Taxonomy and branchial distribution patterns. Publ. Seto Mar. Biol. Lab. 31 (3/6): 269-325.

. 1987. New or little known species of the family Eunicidae (Annelida Polychaeta) from Japan. Proc. Jour. Soc. Syst. Zool. 36: 1-9.

Morgado, E.H. \& A.C.Z. AmARAL. 1981. Anelídeos poliquetos associados a um briozoário. I. Eunicidae, Lumbrineridae, Lysaretidae e Dorvilleidae. Iheringia, Sér. Zool., Porto Alegre, 60: 33-54.

Nogueira, J.M.M.; T.M. Steiner \& A.C.Z. Amaral. 2001. Description of Two New Species of Eunice Cuvier, 1817 (Polychaeta: Eunicidae) from Islands off the Coast of São Paulo State, Brazil. Sci. Mar. 65: 47-57.

Nonato, E.F. \& J.A.C. LunA. 1970 Anelídeos poliquetas do Nordeste do Brasil. I. Poliquetas bentônicas da costa de Alagoas e Sergipe. Bol. Inst. Oceanogr., São Paulo, 19: 57-130.

Orensanz, J.M. 1990. The eunicemorph polychaetes from Antartic and Subantartic seas, p. 1-183. In: L.S. Kornicker (Ed.). Biology of the Antartic Seas XXI. Antartic Res. Ser. 52. Washington, D.C., American Geophysical Union, Ed., 219p.

ORRHAGE, L. 1995. On the innervation and homologues of the anterior end appendages of the Eunicea (Polychaeta), with a tentative outline of a fundamental constitution of the cephalic nervous system of polychaetes. Acta zool. Stockholm 72: 233-246.

Rullier, F. \& L. Amoureux. 1979. Annélides polychètes. Campagne de la Calypso au large des côtes atlantiques de l'Amérique du Sud (1961-1962). Ann. Inst. océanogr. 55: 10-206.

VerRILl, A.E. 1900. Additions to the Turbellaria, Nemertinea, and Annelida of the bermudas. Trans. Conn. Acad. Arts Sci. 10 (2): 595-670.

Zanol, J.; P.C. PAiva \& F.S. AtTolini. 2000. Eunice and Palola (Eunicidae: Polychaeta) from the eastern

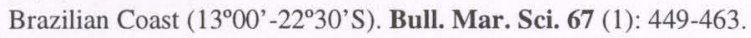

Received in 15.XII.2000; accepted in 29.VI.2002. 